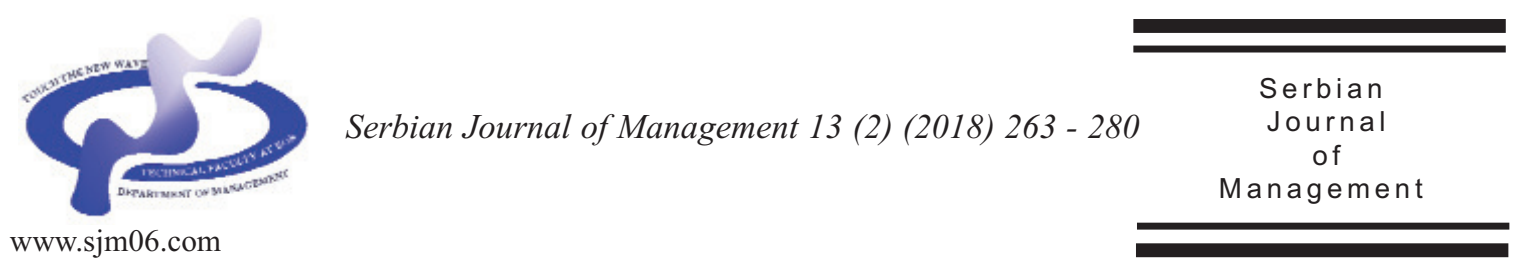

\title{
THE ENTREPRENEURIAL PASSION-ENTREPRENEURIAL ALERTNESS RELATIONSHIP: THE MODERATING ROLE OF A CREATIVE PERSONALITY
}

\author{
Héctor Montiel-Campos \\ Universidad de las Américas Puebla, School of Business and Economics, \\ San Andrés Cholula, Puebla, 72810, Mexico
}

(Received 15 December 2017; accepted 27 March 2018)

\begin{abstract}
Passion has been recognized as an important element in the field of entrepreneurship. However, we know little about the nature and effects of entrepreneurial passion. This research addressed this issue by exploring entrepreneurial passion as an antecedent of entrepreneurial alertness as well as the moderating effect of a creative personality in this relationship. Hypotheses were formulated from the literature review and they were tested on a sample of 406 individuals with primarily business backgrounds in 2016 in Mexico. Results suggested that individuals with a higher degree of entrepreneurial passion were more likely to show greater entrepreneurial alertness. However, creative personality as a moderating variable had minimal effects on this relationship. The main findings and implications of the obtained results, as well as the limitations and suggestions for future research in the field of entrepreneurship are discussed. Findings from this research suggest and encourage others to develop this research stream.
\end{abstract}

Keywords: entrepreneurial passion, entrepreneurial alertness, creativity

\section{INTRODUCTION}

Passion is a topic that has been recently incorporated into the study of entrepreneurship. According to McMullen and Shepherd (2006), passion is not entrepreneurial unless it triggers action. Passion can potentially influence several key activities of the entrepreneurial process, such as opportunity recognition, acquisition of resources, and the capacity to respond to rapid change in dynamic environments (Baron, 2008). Moreover, passion has been associated with an entrepreneur's ability for inventing new products or services, founding new organizations, and developing these

* Corresponding author: hector.montiel@udlap.mx

DOI: $10.5937 / \mathrm{sjm} 13-16021$ 
organizations beyond their initial survival (Cardon et al., 2009; 2012). However, Cardon et al. (2009) declare that "despite the widespread fascination with entrepreneurial passion, it has not been studied systematically, and existing research is fragmented."

The literature review suggests that highly activated and positive emotional states such as passion encourages creativity and recognition of new information patterns that indicate the possible existence of entrepreneurial opportunities (Baron, 2008; Cardon et al., 2009). For example, some studies (Baron \& Tang, 2011; Tang et al., 2012; Cardon et al., 2013) suggest that the passion plays an important role in what is called by Kirzner (1979) "the entrepreneurial alertness", that is, the ability of people to identify opportunities and introduce new products or services on the market. In essence, alertness involves some aspects of perception (Kirzner, 1979), and passion in turn has strong effects on perception (Baron, 2008). Therefore, it seems reasonable to suggest that entrepreneurial passion influences entrepreneurial alertness. Taken together, the arguments in this study have raised questions that guide the efforts of this research. What is the impact of entrepreneurial passion on individual efforts to identify entrepreneurial opportunities? Moreover, does the entrepreneurial passion act alone or does it interact with other capabilities that facilitate the identification of opportunities? The objective of this paper is to answer these questions, which are important for the field of entrepreneurship.

Empirical evidence suggest that positive affect tends to enhance creativity, which, in turn, has been found to be related to opportunity identification. Baron (2008) provides further insight into the mechanisms that affect enhance creativity and, hence, opportunity recognition. Baron (2008) suggests that affect encourages what is known as creative cognition; thus it is a process in which existing cognitive frameworks are expanded or combined to suggest new ideas (Ward, 2004). In this sense, passion facilitates creation of unusual associations, enabling entrepreneurs to engage in novel and creative paths of action. In other words, the person who identifies an entrepreneurial opportunity is required to act creatively (Gielnik et al., 2012).

Creativity literature indicates that there are different factors that contribute to people's creativity (Shalley et al., 2004; Dayan et al., 2013). One of these factors is a creative personality, that is, stable personal characteristics that influence how creatively a person behaves in a variety of domains (Kozbelt et al., 2010). Shane and Nicolauo (2015) recognizes that extant research has not yet examined whether people with creative personalities are more likely than others to identify entrepreneurial opportunities. Therefore, this study explores if a creative personality indirectly influences the relationship between entrepreneurial passion and entrepreneurial alertness.

According to the previous arguments, this study makes three important contributions to the study of entrepreneurship. First, this study adds to the efforts to understand the effects of entrepreneurial passion (Cardon et al., 2012; 2013) and the antecedents of entrepreneurial alertness (Tang et al., 2012; Valliere, 2013a). Second, based on literature review, this study is among the first to empirically investigate the relationship between entrepreneurial passion and entrepreneurial alertness. Finally, it reflects the recommendation of Fillis and Rentschler (2010) and Shane and Nicolaou (2015) to 
include the creative personality in the study of entrepreneurship, in this case as a moderating variable in the entrepreneurial passion -entrepreneurial alertness relationship.

The next section of this document includes a review of the literature and the working hypotheses. Subsequently, the methodology is developed, which describes the characteristics of the participants as well as the measurements and data analysis. The subsequent section shows the study's main results. Finally, the discussion of the results is presented.

\section{LITERATURE REVIEW HYPOTHESES}

\subsection{Entrepreneurial entrepreneurial alertness \\ passion}

and

The literature review shows that affect or emotion, whether positive or negative, is considered a predecessor of certain entrepreneurial actions (Baron, 2008; Cardon et al., 2012), including the ability to influence employees to act entrepreneurially, the risk perception, the level of effort for future tasks, the evaluation of an entrepreneurial opportunity, the setting of goals and satisfaction with the results, the fostering of creativity (Baron \& Tang, 2011; Foo, 2011; Chan \& Park, 2013), and the decision to concentrate or diversify investments.

Recently, there has been discussion on the advisability of incorporating the entrepreneurial passion into entrepreneurship studies (Cardon, 2008; Cardon et al., 2009; 2012). Some even believe that entrepreneurship is a "tale of passion" (Cardon et al., 2005). Overall,
Vallerand et al. (2003) define passion as "a strong inclination toward an activity that people like, that they find important." Philippe et al. (2010) consider it a strong desire to participate in certain activities. In the entrepreneurship field, Cardon et al., (2009) have conceptualized it as "consciously accessible, intense positive feelings experienced by engagement in entrepreneurial activities that are associated with roles meaningful and salient to the selfidentity of the entrepreneur."

There are few studies that have empirically studied the entrepreneurial passion. Some of the results are that passion increases entrepreneurs' persistence and motivation and internalizes ventures' development as personal events (Bird, 1989). Moreover, founders' passion is associated with the lowest likelihood of organizational failure (Baron \& Hannan, 2002). However, an entrepreneur's cognitive passion rather than affective passion has a significantly positive effect on venture capitalists' funding decisions (Chen et al., 2009). Mitteness et al. (2012) analyze the relationship between perceived entrepreneurial passion and evaluation of possible financing. Via role conflict, Thorgren and Wincent (2013) discover that harmonious passion has an indirect positive relationship with role opportunity search, whereas obsessive passion has an indirect negative relationship with role opportunity search. Recently, it has been shown that entrepreneurial passion is positively associated with entrepreneurial self-efficacy and behavior (Murnieks et al., 2014). Moreover, Cardon and Kirk (2015) find that the self-efficacy to a persistence relationship is mediated by some dimensions of entrepreneurial passion.

Cardon et al. (2013) mention that the scarce empirical evidence regarding the 
entrepreneurial passion can be explained by the lack of a measuring instrument. For this reason, the authors developed an instrument that captures the entrepreneurial passion in three different domains of entrepreneurship: passion for inventing new products or services, passion for founding new organizations, and passion for developing these organizations beyond their initial survival and successes. Cardon et al. (2013) declare that "an overall measure of EP across all domains is theoretically inconsistent and should not be used in empirical investigations of the antecedents and/or effects of passion."

The proposal of the entrepreneurial passion, particularly representing the passion for inventing, can be the antecedent of another important element of entrepreneurship known as entrepreneurial alertness (Baron \& Tang, 2011; Tang et al., 2012; Cardon et al., 2013). The origin of entrepreneurial alertness is in Israel Kirzner's theory $(1973 ; 1979)$ in which he initially described it as "the ability to notice without search opportunities that have hitherto been overlooked" (Kirzner, 1979). This proposal greatly influenced the early work that attempted to provide a convincing response to the "without search" idea, but the results were not satisfactory. Later, Gaglio and Katz (2001) mention that some people usually use a schema, which the authors call chronic. The influence of this schema is so strong that the person may not be aware that he or she uses it. This aspect might explain why people identify opportunities even without looking for them. Demmert and Klein (2003) and Kitzmann and Schiereck (2005) also tried to prove the opportunity identification without search behavior, but the results were also not satisfactory.

Gradually the idea that entrepreneurial alertness requires a search behavior became stronger, although this is not systematic. For this reason, alertness is considered a mind state that is open to identifying opportunities at all times (Short et al. 2010; Valliere, 2013b). The lack of a solid theoretical foundation and a reliable measurement instrument has led to the consideration of Kirzner's proposal as being incomplete and weak (McCaffrey, 2013). In this situation, Tang et al. (2012) conceptualize alertness as having three complementary dimensions: scanning and search for new information, connecting previously disparate information, and evaluating whether the new information represents an opportunity. Tang et al. (2012) provide a theoretically justified measure of entrepreneurial alertness, consisting of three components, as described above. Tang et al. (2012) indicate that "the three dimensions of alertness are distinct and measure different aspects of alertness." For this reason, it is not appropriate to group all of the items and obtain only one assessment of entrepreneurial alertness.

Kirzner (2009) recognizes that the purpose of his work was to identify not the factors that stimulate the alertness but the consequences. Despite this, there are works that have theoretically or empirically addressed some antecedents of the entrepreneurial alertness, including knowledge, information availability, immersion in social networks taking advantage of some personality features, the pattern recognition in complex events or trends, self-confidence to move forward with entrepreneurial activities, and diagrams or mental models that help interpret incoming information and make sense of it (Gaglio \& Katz, 2001; Ardichvili et al., 2003; Valliere, 2013a).

Although affect influences the mental 
processes through which a person perceives information, stores it in memory, processes and recovers it for later use (Isen, 2002), the entrepreneurial passion has not been considered as an antecedent of entrepreneurial alertness. Passion facilitates creation of unusual associations, such as recognition of patterns, enabling entrepreneurs to engage in novel and creative paths of action (Baron, 2008). Cardon et al. (2009) suggests that “when an entrepreneur's inventor identity is dominant, entrepreneurial passion will influence the entrepreneur's effectiveness in opportunity recognition, mainly because of its effects on creative problem solving." Such an entrepreneur will be driven toward engagement in creative pursuit of identifying, inventing, and exploring new opportunities or market niches. In essence, a way in which passion may influence opportunity recognition is by acting as an activator or energizer of behavior because passion may intensify the vigor or scope of active searches for potential opportunities, that is, untapped sources of potential profit (Cardon et al., 2009).

In the entrepreneurial process, as suggested by Shane et al. (2003), cognitive elements and people skills are insufficient; thus, it also requires emotional aspects. Kirzner, in one of his works, defined entrepreneurial alertness as "a motivated propensity of man to formulate an image of the future" (Kirzner, 1985). Therefore, it seems reasonable to suggest that strong and positive emotional states for creating or inventing influence on the ability of people to find information on patterns, standards or trends that indicate the possible existence of an entrepreneurial opportunity. This reasoning in more formal terms leads us to propose the following hypothesis:
H1: The domain of passion for inventing of the entrepreneurial passion is positively associated with the scanning and search dimension of the entrepreneurial alertness.

\subsection{Creative personality}

Creativity plays an important role in the entrepreneurial process because entrepreneurs rely on it to devise innovative solutions to overcome resource constraints, to market their products, and to grow their businesses (Zhou, 2008; Fillis \& Rentschler, 2010). Creativity essentially involves the development of a novel idea or solution to a problem that has value for the individual and/or a larger social group (Hennessey \& Amabile, 2010). In fact, creativity is considered a complex construct. Zhou (2008) notes that creativity is not homogeneous, making it difficult to understand, because it is a function of several factors -person, process, and environmentthat can be related to tangible aspects such as a product or the generation of innovative ideas. Creativity is a quality that is attributed to many people and especially to entrepreneurs. That is why Ward (2004) comments that "novel and useful ideas are the lifeblood of entrepreneurship."

Among the determinants of creativity, positive affective states stand out as factors that can be influenced and that have been consistently linked to creativity. The works of Baron (2008) and Hayton and Cholakova (2012) highlight the relationship between positive affect and creativity of the people because it activates cognition and increases cognitive flexibility, which has been empirically proven in various studies (Baas et al., 2008; Baron \& Tang, 2011; Bledow et al., 2013). In the field of entrepreneurship, entrepreneurial passion has been linked to 
creativity and the research of Cardon et al. (2013) illustrates that passion for inventing is related to creative problem-solving. Moreover, the works of Heinonen et al. (2011) and Gielnik et al. (2012) have found a relationship between creativity and idea generation for new products or services.

One important aspect that is not openly considered when working with creativity are the personality traits of those who carry out the entrepreneurial process. For Runco (2007), creativity is a personality trait and a cognitive ability. However, creativity is determined by the personality and other factors (Shalley et al., 2004). Puccio and Grivas (2009) comment that personality traits can help uncover the emotional qualities associated with creativity, both in its style and its process. The relationship between personality traits and creativity has been documented in the literature because both emphasize the uniqueness of the individual (George \& Zhou, 2001; Ardichvili et al., 2003). Kozbelt et al. (2010) argue that, to truly explain creativity, one must also delve more deeply into understanding people, particularly their personalities.

The research on creativity has emphasized various characteristics of individuals successful in creative endeavors suggesting a profile for creative individuals. Feist (1998) stated that "It is safe to say that in general a creative personality does exist and personality dispositions do regularly and predictably relate to creative achievement." A creative personality refers to those personal characteristics and provisions that are stable and consistently lead a person to behave creatively in different fields (Runco, 2007). Creative people have different personality traits from other people, so they have a greater ability to generate new ideas, aspects that are fundamental when the discovery of entrepreneurial opportunities is studied. Several traits have been suggested to be related to creativity; thus, one of the traits closely related to creativity is openness to experience (George \& Zhou, 2001; Dollinger et al., 2004). In fact, of the Five Factor Model dimensions, openness to experience has the most empirical support as being closely related to creativity (Feist, 1998).

Openness to experience is a personality trait that reflects characteristics such as imaginativeness, curiosity, originality, and broadmindedness (McCrae \& Costa, 1987). One element of openness is attentiveness to inner feelings (McCrae \& Costa, 1987). Entwistle (1988) found that students with high level of openness exhibited high level of motivation, too. The ability to see things from different perspectives has been stressed in the creativity literature. Divergent thinking is usually associated with creativity because it stimulates the generation of new ideas and radical problem solving (Im et al., 2013). Openness to experience facilitates multiple perspectives, thereby building interest in the task itself (Prabhu et al., 2008).

Despite the importance that a creative personality could have in the entrepreneurial process, specifically in identifying opportunities, research about this is scarce. Some evidence suggests an association between a creative personality and the tendency to identify entrepreneurial opportunities (Ardichvili et al., 2003; Kirzner, 2009; Heinonen et al., 2011; Shane $\&$ Nicolaou, 2015). However, research does not show conclusively that people with more creative personalities are more likely to identify business opportunities. Kirzner's theory (1999; 2009) mentions that entrepreneurial alertness requires a creative action, which influences the type of actions 
to be undertaken in the future. Kirzner (2009) argues that "To be sure, creativity is much more than alertness. But the creativity that drives profit-winning entrepreneurial behavior is a creativity that embraces alertness too." In this sense, creativity has been linked to the ability of people to search for information, indicating the existence of a possible opportunity (Tang et al., 2012).

According to Hennessey and Amabile (2010), people can have certain traits and skills that are favorable for creativity, but they also depend on their motivation to actually achieve creative results. In other words, the person has to be interested in the issue or problem and motivated to find new alternative solutions (Prabhu et al., 2008). From the arguments developed previously, this study suggests that a creative personality may moderate the relationship between the entrepreneurial passion and entrepreneurial alertness. Therefore, the creative personality's moderating effect arises in the following hypothesis:

H2: The personality trait of openness to experience will moderate the relationship between the domain of passion for inventing of the entrepreneurial passion and the scanning and search dimension of the entrepreneurial alertness.

\section{METHODOLOGY}

\subsection{Participants and procedure}

This research used a purposeful sampling approach, given the difficulties to reach a probabilistic sampling, which is common in entrepreneurship studies. To obtain a relatively homogeneous sample and to ensure participation in the study, the author's personal contacts were used, and a working team was created. Participants in the study had a professional academic education in the business field or at least were completing their studies when this research was conducted. Participants were of different ages, and some had more than two years of professional experience and postgraduate studies.

Prior to the final implementation of the survey, a pilot study with 13 people was performed to ensure correct understanding of the different questions in the survey. From this, the necessary adjustments were made and the final survey was created in 2016. It was possible to contact 425 people to participate in the study, all of them in the central region of Mexico. After collecting 425 surveys, 19 of them were incomplete and were not considered in the final analysis. The study incorporated 406 surveys. The participants' ages ranged from 19 to 58 years, averaging 24.1 years; $52.7 \%$ of the participants were women; $33 \%$ of the participants had postgraduate studies; and $53.2 \%$ had at least two years of professional work experience. The most common majors in the sample were business administration, international business, marketing, accounting, finance, and information technology management.

\subsection{Measures}

\subsubsection{Entrepreneurial passion}

The entrepreneurial passion was measured using the scale of Cardon et al. (2013). Specifically, the domain passion for inventing was selected because people with this domain have the desire and motivation to develop new solutions to existing problems or needs (Cardon et al., 2009). The 
passion for inventing was measured with four items that assess the experience of intense positive feelings toward particular activities plus an item that evaluates the centrality of these activities for the selfidentity of the individual. These two dimensions are conceptually and empirically distinct from one another so that not only the individual effect on other variables but also its complementary or multiplicative effect are analyzed (Cardon et al., 2013). All items were evaluated using a five-point Likert's scale, ranging from 1 (strongly disagree) to 5 (strongly agree).

\subsubsection{Entrepreneurial alertness}

To measure the entrepreneurial alertness, the scale of Tang et al. (2012) was applied, which was also used in the work of Dayan et al. (2013). In this study, the scanning and searching for the information dimension was used because it is the most suited to the original Kirzner's conception of entrepreneurial alertness. This dimension identifies people who are persistent and unconventional, both in searching new ideas and in developing knowledge to help them find answers to specific questions (Tang et al., 2012). This dimension consists of six items that were evaluated using a five-point Likert's scale.

\subsubsection{Creative personality}

This study used the Five Factor Model for stability and robustness, which has been shown in the classification of personality traits (Rantanan et al., 2007). Specifically, we explored the openness to experience factor and measured it with the International Personality Item Pool (IPIP, 1999) 50 item scale that measures the five broad domains of the Five Factor Model. Participants were presented with ten items that represent openness to experience and were asked to indicate how accurately each one describes them on a five-point Likert's scale.

\subsubsection{Control variables}

Four control variables were considered, all at the individual level: age, gender (female $=0$; male $=1)$, education $(0=$ bachelor; 1 = graduate) and at least two years of work experience (no experience $=0$; experience $=1$ ). Previous studies have considered these variables to have an influence on activities performed in the entrepreneurial process (Bledow et al., 2013).

\subsection{Data analysis}

Prior to the final analysis, some tests were performed with the data. First, the sample size was verified, so that the response rate was observed. The index was 19.3:1, exceeding the 5:1 recommendation rule (Hair et al., 2006). Subsequently, the data normality was analyzed using the skewness and kurtosis tests. The tests did not produce values that indicate any type of problem.

Before testing the hypotheses, the model's discriminant validity was evaluated. First, the measure of sample adequacy was performed (Hair et al., 2006). The statistics showed that the global Kaiser-Meyer-Olkin (KMO) measure was 0.92 and the individual KMO was 0.89 , both higher than the recommended threshold of 0.60 . Once this was completed, a confirmatory factor analysis (CFA) was performed. The model fit was then assessed using the goodness-of-fit index (GFI), the comparative fit index (CFI), and the $\chi^{2} / \mathrm{df}$. The analysis started with one- 
factor model where all the items for the four scales (intense positive feelings, identity centrality, creative personality and scanningsearch) are loaded on one factor. The results indicated that the model did not fit the data $\left(\mathrm{GFI}=0.56, \mathrm{CFI}=0.68, \chi^{2} / \mathrm{df}=4.5\right)$. Next, a three-factor model was estimated, where intense positive feelings and identity centrality were combined on one factor. The model fit improved significantly (GFI $=0.88$, $\left.\mathrm{CFI}=0.90, \chi^{2} / \mathrm{df}=3.1\right)$. Finally, a four-factor model was estimated with one factor representing each variable. According to the values of GFI and CFI, as well as the threshold for $\chi^{2 / \mathrm{df}}$ recommended by Premkumar and King (1994), the model fit improved slightly (GFI $=0.92, \mathrm{CFI}=0.91$, $\chi^{2} / \mathrm{df}=2.5$ ). Based on these statistics, the final analysis was done with four factors.

To further explore the four dimensions' discriminant validity, the procedure described by Fornell and Larcker (1981) was followed and the square root of the average variance extracted (AVE) for variables was calculated, except for the identity centrality because it only had one item. The values ( 0.87 for intense positive feelings, 0.82 for creative personality and to 0.85 for scanningsearch) were satisfactory as they were higher than the correlations with other variables shown in the analysis. The above results indicate that the variables are different from one another, and thus the satisfactory discriminant validity is suggested. The internal validity of each variable was then assessed using Cronbach's alpha, which was 0.79 for intense positive feelings, 0.73 for creative personality and 0.78 for scanningsearch. All of these values are within the acceptable range because they are higher than 0.70 (Hair et al., 2006).

To test the hypothesis, a hierarchical regression analysis was performed and the degree of association between the study variables was determined. There were nine models in which independent variables were added and the multiplier effects between them were identified. The dependent variable in all models was the entrepreneurial alertness.

\section{RESULTS}

Table 1 shows the means, standard deviations and correlations for all variables in the study. It is important to identify the relationships between the main variables of the study. First, the relationship between the two variables of the entrepreneurial passion (intense positive feelings and identity centrality) is strong and significant ( $r=0.50$, $p<0.001$ ), as predicted by the theory (Cardon et al., 2013). Next, the important relationship lies between entrepreneurial passion and entrepreneurial alertness, and these relations are the strongest and most significant in this analysis ( $r=0.71$ and $r=0.55$, respectively), an aspect also mentioned in the literature (Baron, 2008; Tang et al., 2012; Cardon et al., 2013). Finally, it is important to note the relationship between creative personality and entrepreneurial alertness, which was also positive and significant $(r=0.42, p<0.001)$, consistent with previous results (Shane \& Nicolauo, 2015).

The hypothesis testing was performed using hierarchical regression analysis. Hypothesis 1 stated that the entrepreneurial passion was positively associated with entrepreneurial alertness. To test the hypothesis, the individual and combined effects of intense positive feelings and identity centrality were observed. In Table 2, Models 2 and 3 show that feelings and 
Table 1. Means, standard deviations, and correlations

\begin{tabular}{|c|c|c|c|c|c|c|c|c|c|}
\hline Variables & Mean & S.D. & $\mathbf{1}$ & 2 & 3 & 4 & 5 & 6 & 7 \\
\hline 1. Age & 24.06 & 6.16 & & & & & & & \\
\hline 2. Gender & 0.47 & 0.50 & 0.07 & & & & & & \\
\hline 3. Education & 0.33 & 0.47 & $0.72 * * *$ & $0.14 * *$ & & & & & \\
\hline 4. Experience & 0.53 & 0.52 & $0.51 * * *$ & 0.06 & $0.51 * * *$ & & & & \\
\hline 5. IPF-inventing ${ }^{\mathrm{a}}$ & 4.00 & 0.79 & 0.003 & -0.05 & -0.03 & 0.001 & & & \\
\hline 6. IC-inventing ${ }^{\mathrm{b}}$ & 3.73 & 0.97 & $0.13 * *$ & 0.06 & $0.12 *$ & $0.10^{*}$ & $0.50 * * *$ & & \\
\hline 7. Creative personality & 3.8 & 0.54 & 0.04 & 0.05 & $0.11 *$ & 0.09 & $0.37 * * *$ & $0.39 * * *$ & \\
\hline 8. Scanning-search ${ }^{\mathrm{c}}$ & 3.91 & 0.73 & $0.12 *$ & 0.05 & $0.14 * *$ & $0.10 *$ & $0.71 * * *$ & $0.55^{* * *}$ & $0.42 * * *$ \\
\hline
\end{tabular}

Table 2. Results for the hierarchical regression analysis, hypothesis 1

\begin{tabular}{|c|c|c|c|c|c|}
\hline \multirow{2}{*}{ Variables } & \multicolumn{5}{|c|}{ Entrepreneurial alertness (scanning and search) } \\
\hline & Model 1 & Model 2 & Model 3 & Model 4 & Model 5 \\
\hline Age & 0.006 & $0.027 * * * *$ & $0.069 * * * *$ & $0.021 * * * *$ & 0.0002 \\
\hline Gender & 0.040 & $0.144 * * *$ & $0.118^{*}$ & $0.11 * *$ & $0.008^{*}$ \\
\hline Education & 0.126 & -0.003 & $-0.488 * * * *$ & 0.0003 & $0.177 * *$ \\
\hline Experience & 0.043 & 0.011 & -0.066 & -0.0003 & 0.010 \\
\hline IPF-inventing $^{\mathrm{a}}$ & & $0.794 * * * *$ & & $0.651 * * * *$ & $0.827 * * * *$ \\
\hline IC-inventing & & & $0.623^{* * * * *}$ & $0.195^{* * * *}$ & $0.485^{* * * *}$ \\
\hline $\mathrm{IPF} * \mathrm{IC}-$ inventing & & & & & $-0.086 * * * *$ \\
\hline $\mathrm{R}^{2}$ & 1.15 & 58.29 & 56.79 & 58.46 & 58.62 \\
\hline Adjusted $\mathrm{R}^{2}$ & 0.00 & 58.27 & 56.75 & 58.43 & 58.6 \\
\hline$\Delta \mathrm{R}^{2}$ & & 57.14 & -1.5 & 1.67 & 0.16 \\
\hline
\end{tabular}

identity were positively and significantly associated with entrepreneurial alertness $(\beta=$ 0.794 and $\beta=0.623$, respectively, both with $p$ $<0.001)$. In Model 4, there is also evidence of a significant positive relationship when considered simultaneously $(\beta=0.651$ and $\beta=$ 0.195 , respectively, both with $p<0.001)$.

Finally, in Model 5 the positive and significant relationships between feelings and alertness $(\beta=0.827, p<0.001)$ and between identity centrality and alertness $(\beta=$ $0.485, p<0.001)$ are discovered again. The interaction between intense positive feelings and identity centrality with entrepreneurial alertness was negative $(\beta=-0.086, p$ $<0.001)$. This result indicates that the significant and positive relationship between intense positive feelings for inventing and entrepreneurial alertness is lower in magnitude for individuals who report that inventing is less important to their identity than it is for individuals who report that inventing is more important. These results provide support for hypothesis 1 .

The results for hypothesis 2 that proposes a moderating effect of the creative personality on the relationship between entrepreneurial passion and entrepreneurial alertness are shown in Table 3. Models 6, 7 and 8 show that the creative personality is positive and significant (Model 6: $\beta=0.239$; Model 7: $\beta=0.315$; Model 8: $\beta=0.299$, all of them with $p<0.001)$. However, when these were included into the combined effect 
Table 3. Results for the hierarchical regression analysis, hypothesis 2

\begin{tabular}{|c|c|c|c|c|}
\hline \multirow{2}{*}{ Variables } & \multicolumn{4}{|c|}{ Entrepreneurial alertness (scanning and search) } \\
\hline & Model 6 & Model 7 & Model 8 & Model 9 \\
\hline$\overline{\text { Age }}$ & $0.009 * *$ & 0.002 & 0.003 & 0.0008 \\
\hline Gender & 0.071 & 0.061 & 0.064 & 0.067 \\
\hline Education & 0.073 & $0.14^{*}$ & $0.128 *$ & $0.163 * *$ \\
\hline Experience & -0.0003 & 0.002 & 0.007 & 0.0001 \\
\hline IPF-inventing ${ }^{\mathrm{a}}$ & $0.542 * * * *$ & $0.662 * * * *$ & $0.523 * * * *$ & $0.824 * * * *$ \\
\hline IC-inventing ${ }^{\mathrm{b}}$ & $0.144 * * * *$ & $0.148^{* * * *}$ & $0.275^{* * * *}$ & $0.490 * * * *$ \\
\hline $\mathrm{IPF} * \mathrm{IC}$-inventing & & & & $-0.133 * * *$ \\
\hline $\mathrm{CP}^{\mathrm{c}}$ & $0.239 * * * *$ & $0.315^{* * * *}$ & $0.299 * * * *$ & 0.031 \\
\hline IPC-inventing $* \mathrm{CP}^{\mathrm{c}}$ & & $-0.039 * * *$ & & \\
\hline IC-inventing $* \mathrm{CP}^{\mathrm{c}}$ & & & $-0.035 * *$ & \\
\hline $\mathrm{IPF} *$ IC-inventing $* \mathrm{CP}^{\mathrm{c}}$ & & & & $0.010^{*}$ \\
\hline $\mathrm{R}^{2}$ & 58.59 & 58.62 & 58.61 & 58.67 \\
\hline Adjusted $\mathrm{R}^{2}$ & 58.57 & 58.59 & 58.58 & 58.64 \\
\hline$\Delta \mathrm{R}^{2}$ & 57.44 & 0.03 & -0.01 & 0.06 \\
\hline
\end{tabular}

with intense positive feelings and identity centrality, their contribution was negative (Model 7: $\beta=-0.039, p<0.01$; and Model. $8: \beta=-0.035, p<0.05)$. Finally, the results from Model 9 provide information for hypothesis 2 , including the individual effect of intense positive feelings $(\beta=0.824, p$ $<0.001$ ), identity centrality $(\beta=0.490, p$ $<0.001)$, their combined effect $(\beta=-0.133$, $p<0.01$ ), and the interaction between intense positive feelings, identity centrality and creative personality $(\beta=0.01, p<0.1)$. These results show that the creative personality has a very small moderating effect, which leads us to reject hypothesis 2 .

\section{DISCUSSION}

\subsection{Key findings and implications}

This study investigated the relationship between dimensions of entrepreneurial passion and entrepreneurial alertness. The choice of these variables was based on previous studies indicating that both are important in the entrepreneurial process (Baron, 2008; Tang et al., 2012; Cardon et al., 2013). It has recently been suggested, based on data from these studies, that entrepreneurial passion can influence other entrepreneurial actions, specifically the ability of individuals to identify entrepreneurial opportunities (Cardon et al., 2012; 2013), that is, their entrepreneurial alertness (Kirzner, 2009).

This research provides empirical evidence for the relationship between passion for inventing (entrepreneurial passion) and scanning and search for information (entrepreneurial alertness). The results indicate that a person's passion is significantly related to his or her entrepreneurial alertness, which is consistent with previous results in this line of reasoning (Foo, 2011; Hayton \& Cholakova, 2012). As suggested by Cardon et al. (2013), individual and multiplicative influence of feelings and identity centrality on entrepreneurial alertness was tested. Models 2 to 5 in Table 2 show that feelings are always more representative than identity centrality. This 
aspect is confirmed in Model 5 when considering the combined effect on entrepreneurial alertness; a negative relationship exists, although it is weak and meaningful.

The higher representativeness of intense positive feelings in comparison with identity centrality is consistent with Cardon et al. (2013) because it confirms that passion for inventing is more enduring than the experience of episodic emotions associated with external stimuli. Besides, when individuals are passionate about an activity, they cannot help but to think about that activity (Chen et al., 2009). Another explanation of this result is that these feelings are experienced for activities that are not necessarily meaningful to the selfidentity of the individual. It means that passion for inventing is at least partially reflected in the role that the entrepreneurs enact in this study. Stryker and Burke (2000) argue that individuals organize their identities hierarchically. These variations in identity lead entrepreneurs to engage in activities they identify more closely with and to disengage from those with which they do not. This result is consistent with the view that not all entrepreneurs are alike when it comes to their identity (Fauchart \& Gruber, 2011).

Research results additionally demonstrate the effect of a creative personality as a moderator variable in the relationship between entrepreneurial passion and entrepreneurial alertness. This assumption was made based on the previous work in this area (Heinonen et al., 2011; Gielnik et al., 2012; Shane \& Nicolaou, 2015). As seen in Table 3, Model 9, the creative personality influence as a moderator was not strong enough $(\beta=0.010)$, although its level of significance $(p<0.10)$ suggests that it should be included in the regression model. The result indicates that a creative personality has a fairly discreet intervention. A possible explanation for this result is that a person does not necessarily have to be very creative to identify business opportunities. Although this study was not specifically designed to explain the mechanisms underlying this moderating effect, it requires additional research to clarify the precise mechanisms through which a creative personality contributes to the expansion or combination of existing knowledge structures, thereby identifying opportunities (Ward, 2004). This result confirms previous comments about the difficulty of studying creativity, which is exacerbated by its interactions with other variables (Shalley et al., 2004).

\subsection{Limitations and suggestions for future research}

The results of this research should be viewed in light of its limitations, so that the limitations may be considered in future research. The nature of the sample is a first limitation because all of the participants had professional training in business. This may explain the strong relationship that arose between entrepreneurial passion and entrepreneurial alertness, and perhaps it influenced the creative personality of the sample. In addition, although the sample size was sufficient, all participants were in the central region of Mexico. Future work could consider a more heterogeneous sample profile of participants in order to confirm if academic education in the business field really explains the strong relationship between passion and alertness. Besides, future research could incorporate entrepreneurial experience, that is, if participants previously have created a new 
venture or participated in some similar experience. This proposal could benefit future research of types of human capital related to the entrepreneurship process, specifically opportunity identification (Marvel et al., 2016).

Based on the results obtained in this study and previous studies (Baas et al., 2008; Baron \& Tang, 2011; Bledow et al., 2013), it is recommended that, in future research, the creative personality be evaluated as an intermediate variable in the relationship of entrepreneurial passion and entrepreneurial alertness. The obtained correlation and regression coefficients in this study lead us to suppose that the entrepreneurial passion would be related to the creative personality, which, in turn, would be related to entrepreneurial alertness. To test these relationships, future studies should consider other analysis techniques. It is important to remember that creativity is a complex construct; therefore, the new design of the sample could overcome the limitations that this study previously has discussed.

Moreover, this work just incorporated a domain of entrepreneurial passion (passion for inventing) and a dimension of entrepreneurial alertness (scanning and search for information). Although the recommendations of Cardon et al. (2013) and Tang et al. (2012) are not to combine domains and dimensions, it would be interesting to incorporate the three domains of entrepreneurial passion or the three dimensions of entrepreneurial alertness in a study. Future research should consider the possibility to include in the same study passion for inventing, passion for founding, and passion for developing in order to identify if one domain is dominant. Besides, the three dimensions of entrepreneurial alertness should be included to evaluate if one specific dimension of the process is related with one domain of the entrepreneurial passion. For this, it would be advisable to have a sample of experienced entrepreneurs to make a good assessment of the instruments and to get reliable results.

Finally, it is important that future studies relate passion and alertness to other variables within the entrepreneurial process, e.g., to analyze the entrepreneurial passion role in the entrepreneurial intentions (Lee et al., 2011). In addition, entrepreneurial alertness could help us to better understand entrepreneurial decision-making or the firm's entrepreneurial orientation (Shepherd et al., 2015).

\subsection{Contributions and conclusion}

Despite the limitations, this study suggests at least three contributions to the field of entrepreneurship. First, this work is one of the few studies that have empirically validated the relationship among entrepreneurial passion, creative personality, and entrepreneurial alertness, as has been suggested by Shane and Nicolaou (2015). It is important to declare that this study used scales recently developed for measuring these variables (Tang et al., 2012; Cardon et al., 2013), which contribute to the research in the fields of entrepreneurship and creativity. Second, the results of this study provide empirical evidence to suggest that people's entrepreneurial passion can stimulate their entrepreneurial alertness, as has been suggested in previous studies (Baron \& Tang, 2011; Foo, 2011; Hayton \& Cholakova, 2012; Tang et al., 2012; Cardon et al., 2013). As argued by Baron (2008) and Cardon et al. (2009), the influence of affect or passion on behavior may be especially important in the case of entrepreneurs. Third, 
the results confirm the complexity of incorporating creativity in the entrepreneurial process. Consequently, our understanding of a creative personality's role as a moderator in the passion-alertness entrepreneurial relationship is limited. The results obtained here show a discreet intervention of the creative personality and, therefore, contribute to the interest of better understanding the mechanisms through which creativity is involved in entrepreneurial activities (Bledow et al., 2013).

Understanding the forces that support or inhibit entrepreneurial alertness is a central topic of the field of entrepreneurship. This study has proposed that passion has an influence on cognitive activity of individuals and makes it through the entrepreneurial alertness. For instance, on the basis of the present findings, it concludes that entrepreneurial passion for inventing among individuals may encourage a creative personality as well as the scanning and search dimension of the entrepreneurial alertness. However, the results are not strong enough to support that a creative personality influences indirectly on entrepreneurial alertness when it is combined with entrepreneurial passion. Therefore, more work is necessary to confirm the results obtained in this study.

It has hope that this work is one of the first to tackle this fascinating subject and encourage others to develop future contributions in this area. Excitingly, future research can respond to the call to explore how emotional and cognitive aspects are equally important in the study of entrepreneurship because they interact to shape entrepreneurial behaviors.

\section{References}

Ardichvili, A., Cardozo, R., \& Ray, S. (2003). A theory of entrepreneurial opportunity identification and development. Journal of Business Venturing, 18(1), 105123.

Baas, M., De Dreu, C.K.W., \& Nijstad, B.A. (2008). A meta-analysis of 25 years of mood-creativity research: hedonic tone, activation, or regulatory focus? Psychological Bulletin, 134(6), 779-806.

Baron, R.A. (2008). The role of affect in the entrepreneurial process. Academy of Management Review, 33(2), 328-340.

Baron, J.N., \& Hannan, M.T. (2002). Organizational blueprints for success in high-tech start-ups: lessons from the Stanford Project on emerging companies. California Management Review, 44(3), 8-36.

Baron, R.A., \& Tang, J. (2011). The role of entrepreneurs in firm-level innovation: joint effects of positive affect, creativity, and environmental dynamism. Journal of Business Venturing, 26(1), 49-60.

Bird, B.J. (1989). Entrepreneurial behavior. Glenview, IL: Scott Foresman.

Bledow, R., Rosing, K., \& Frese, M. (2013). A dynamic perspective on affect and creativity. Academy of Management Journal, 56(2), 432-450.

Cardon, M.S. (2008). Is passion contagious? The transference of entrepreneurial passion to employees. Human Resource Management Review, 18(2), 77-86.

Cardon, M.S., Foo, M.D., Shepherd, D.A., \& Wiklund, J. (2012). Exploring the heart: entrepreneurial emotion is a hot topic. Entrepreneurship Theory and Practice, 36(1), $1-10$.

Cardon, M.S., Gregoire, D.A., Stevens, C.E., \& Patel, P. (2013). Measuring 


\title{
ОДНОС ИЗМЕЪУ ПРЕДУЗЕТНИЧКЕ СТРАСТИ И ПРЕДУЗЕТНИЧКЕ ОПРЕЗНОСТИ - МОДЕРАТОРСКА УЛОГА КРЕАТИВНЕ ЛИЧНОСТИ
}

\author{
Héctor Montiel-Campos
}

\section{Извод}

Страст је препозната као важан елемент у области предузетништва. Међутим, мало знамо о природи и ефектима предузетничке страсти. Ово истраживање се бави овом темом кроз истраживање предузетничке страсти као претходника предузетничке пажње, као и ублажавајућег ефекта креативне личности у овом односу. Хипотезе су формулисане из прегледа литературе и тестиране су на узорку од 406 особа, које имају превасходно пословно искуство у области предузетништва, током 2016. години у Мексику. Резултати су показали да су особе са вишим степеном предузетничке страсти показале већу предузетничку свест. Међутим, креативна личност као промењива варијабла имала је минималне утицаје на овај однос. Разматрани су главни налази и импликације добијених резултата, као и ограничења и сугестије за будуће истраживање у области предузетништва. Налази из овог истраживања сугеришу и охрабрују друге да развијају овај истраживачки правац.

Кључне речи: предузетничка страст, предузетничка опрезност, креативност

entrepreneurial passion: conceptual foundations and scale validation. Journal of Business Venturing, 28(3), 373-396.

Cardon, M.S., \& Kirk, C.P. (2015). Entrepreneurial passion as mediator of the self-efficacy to persistence relationship. Entrepreneurship Theory and Practice, 39(5), 1027-1050.

Cardon, M.S., Wincent, J., Singh, J., \& Drnovsek, M. (2009). The nature and experience of entrepreneurial passion. Academy of Management Review, 34(3), 511-532.

Cardon, M.S., Zietsma, C., Saparito, B., Matherne, P., \& Davis, C. (2005). A tale of passion: new insights into entrepreneurship from a parenthood metaphor. Journal of Business Venturing, 20(1), 23-45.

Chan, C.S.R., \& Park, H.D. (2013). The influence of dispositional affect and cognition on venture investment portfolio concentration. Journal of Business Venturing, 28(3), 397-412.

Chen, X.P., Yao, X., \& Kotha, S. (2009). Passion and preparedness in entrepreneurs' business plan presentations: a persuasion analysis of venture capitalists' funding decisions. Academy of Management Journal, 52(1), 199-214.

Dayan, M., Zacca, R., \& DiBenedetto, A. (2013). An exploratory study of entrepreneurial creativity: its antecedents and mediators in the context of UAE firms. Creativity and Innovation Management, 22(3), 223-240.

Demmert, H., \& Klein, D.B. (2003). Experiment on entrepreneurial discovery: an attempt to demonstrate the conjecture of Hayek and Kirzner. Journal of Economic Behavior and Organization, 50(3), 295-310.

Dollinger, S.J., Urban, K.K., \& James, T.A. (2004). Creativity and openness: further 
validation of two creative product measures. Creativity Research Journal, 16(1), 35-47.

Entwistle, N. (1988). Motivational factors in students' approaches to learning. In R.R. Schmeck (Ed.), Learning strategies and learning styles. New York: Plenum Press, 2149.

Fauchart, E., \& Gruber, M. (2011). Darwinians, communitarians and missionaries: the role of founder identity in entrepreneurship. Academy of Management Journal, 54(5), 935-957.

Feist, G.J. (1998). A meta-analysis of personality in scientific and artistic creativity. Personality and Social Psychology Review, 2(4), 290-309.

Fillis, I., \& Rentschler, R. (2010). The role of creativity in entrepreneurship. Journal of Enterprising Culture, 18(1), 49-81.

Foo, M. (2011). Emotions and entrepreneurial opportunity evaluation. Entrepreneurship Theory and Practice, 35(2), 375-393.

Fornell, C., \& Larcker, D. (1981). Evaluating structural equation models with unobservable variables and measurement error. Journal of Marketing Research, 18(1), 39-50.

Gaglio, C.M., \& Katz, J.A. (2001). The psychological basis of opportunity identification: entrepreneurial alertness. Small Business Economics, 16(2), 95-111.

George, J.M., \& Zhou, J. (2001). When openness to experience and conscientiousness are related to creative behavior: an interactional approach. Journal of Applied Psychology, 86(3), 133-142.

Gielnik, M.M., Frese, M., Graf, J.M., \& Kampschulte, A. (2012). Creativity in the opportunity identification process and the moderating effect of diversity of information. Journal of Business Venturing, 27(5), 559-576.
Hair, J.E., Black, W.C., Babin, B.J., Anderson, R.E., \& Tatham, R.L. (2006). Multivariate data analysis (Sixth edition). Upper Saddle River, NJ: Prentice Hall.

Hayton, J.C., \& Cholakova, M. (2012). The role of affect in the creation and intentional pursuit of entrepreneurial ideas. Entrepreneurship Theory and Practice, 36(1), 41-67.

Heinonen, J., Hytti, U., \& Stenholm, P. (2011). The role of creativity in opportunity search and business ideas creation. Education + Training, 53(8/9), 659-672.

Hennessey, B.A., \& Amabile, T.M. (2010). Creativity. Annual Review of Psychology, 61(1), 569-598.

Im, S., Montoya, M.M., \& Workmen, J.P. (2013). Antecedents and consequences of creativity in product innovation teams. Journal of Product Innovation Management, 30(1), 170-185.

International Personality Item Pool IPIP. (1999). International Personality Item Pool: A Scientific Collaboratory for the Development of Advanced Measures of Personality Traits and Other Individual Differences. Retrieved January 10, 2016 from http://www.ipip.ori.org/

Isen, A.M. (2002). Missing in action in the AIM: positive affect's facilitation of cognitive flexibility, innovation, and problem solving. Psychological Inquiry, 13(1), 57-65.

Kirzner, I.M. (1973). Competition and entrepreneurship. Chicago, IL: University of Chicago Press.

Kirzner, I.M. (1979). Perception, opportunity, and profit. Chicago, IL: University of Chicago Press.

Kirzner, I.M. (1985). Discovery and the capitalist process. Chicago, IL: University of Chicago Press.

Kirzner, I.M. (1999). Creativity and/or 
alertness: a reconsideration of the to higher evaluations of funding potential. Schumpeter entrepreneur. The Review of Journal of Business Venturing, 27(5), 592Austrian Economics, 11(1), 5-17. 606.

Kirzner, I.M. (2009). The alert and creative entrepreneur: a clarification. Small Business Economics, 32(2), 145-152.

Kitzmann, J., \& Schiereck, D. (2005). Entrepreneurial discovery and the Demmert/Klein experiment: another attempt at creating the proper context. The Review of Austrian Economics, 18(2), 169-178.

Kozbelt, A., Beghetto, R.A., \& Runco, M.A. (2010). Theories of creativity. In J. C. Kaufman \& R. J. Sternberg (Eds.), Handbook of creativity. Cambridge: Cambridge University Press.

Lee, L., Wong, P.K., Foo, M.D., \& Leung, A. (2011). Entrepreneurial intentions: the influence of organizational and individual factors. Journal of Business Venturing, 26(1), 124-136.

Marvel, M.R., Davis, J.L., \& Sproul, C.R. (2016). Human capital and entrepreneurship research: a critical review and future directions. Entrepreneurship Theory and Practice, 40(3), 599-626.

McCaffrey, M. (2013). On the theory of entrepreneurial incentives and alertness. Entrepreneurship Theory and Practice, 38(4), 891-911.

McCrae, R.R., \& Costa, P.T. (1987). Validation of the five-factor model of personality across instruments and observers. Journal of Personality and Social Psychology, 52(1), 81-90.

McMullen, J.S., \& Shepherd, D.A. (2006). Entrepreneurial action and the role of uncertainty in the theory of the entrepreneur. Academy of Management Review, 31(1), 132-152.

Mitteness, C., Sudek, R., \& Cardon, M.S. (2012). Angel investor characteristics that determine whether perceived passion leads

Murnieks, C.Y., Mosakowski, E., \& Cardon, M.S. (2014). Pathways of passion: identity centrality, passion, and behavior among entrepreneurs. Journal of Management, 40(6), 1583-1606.

Philippe, F.L., Vallerand, R.J., Houlfort, N., Lavigne, G.L., \& Donahue, E.G. (2010). Passion for an activity and quality of interpersonal relationships: the mediating role of emotions. Journal of Personality and Social Psychology, 98(6), 917-932.

Prabhu, V., Sutton, C., \& Sauser, W. (2008). Creativity and certain personality traits: understanding the mediating effect of intrinsic motivation. Creativity Research Journal, 20(1), 53-66.

Premkumar, G., \& King, W.R. (1994). Organizational characteristics and information systems planning: an empirical study. Information Systems Research, 5(2), 75-109.

Puccio, G.J., \& Grivas, C. (2009). Examining the relationship between personality traits and creativity styles. Creativity and Innovation Management, 18(4), 247-255.

Rantanan, J., Metsapelto, R.L., Feldt, T., Pulkkinen, L., \& Kokko, K. (2007). Longterm stability in the big five personality traits in adulthood. Scandinavian Journal of Psychology, 48(6), 511-518.

Runco, M.A. (2007). Creativity. Theories and themes: research, development and practice. Burlington, MA: Elsevier Academic Press.

Shane, S., Locke, E.A., \& Collins, C.J. (2003). Entrepreneurial motivation. Human Resource Management Review, 13(2), 257279.

Shane, S., \& Nicolaou, N. (2015). 
Creativity personality, opportunity recognition and the tendency to start business: a study of their genetic predispositions. Journal of Business Venturing, 30(3), 407-419.

Shalley, C., Zhou, J., \& Oldham, G. (2004). The effects of personal and contextual characteristics on creativity: where should we go from here? Journal of Management, 30(6), 933-958.

Shepherd, D.A., Williams, T.A., \& Patzelt, H. (2015). Thinking about entrepreneurial decision making. Review and research agenda. Journal of Management, 41(1), 11-46.

Short, J.C., Ketchen, D.J., Shook, C.L., \& Ireland, R.D. (2010). The concept of opportunity in entrepreneurship research: past accomplishments and future challenges. Journal of Management, 36(1), 40-65.

Stryker, S., \& Burke, P.J. (2000). The past, present, and future of an identity theory. Social Psychology Quarterly, 63(4), 284297.

Tang, J., Kacmar, K.M., \& Busenitz, L. (2012). Entrepreneurial alertness in the pursuit of new opportunities. Journal of Business Venturing, 27(1), 77-94.

Thorgren, S., \& Wincent, J. (2013). Passion and role opportunity search: interfering effects of conflicts and overloads. International Journal of Stress Management, 20(1), 20-36.

Vallerand, R.J., Blanchard, C., Mageau, G.A., Koestner, R., Ratelle, C., Leonard, M., Gagne, M., \& Marsolais, J. (2003). Les passions de l'ame: on obsessive and harmonious passion. Journal of Personality and Social Psychology, 85(4), 756-767.

Valliere, D. (2013a). Towards a schematic theory of entrepreneurial alertness. Journal of Business Venturing, 28(3), 430-442.

Valliere, D. (2013b). Entrepreneurial alertness and paying attention. Journal of Enterprising Culture, 21(1), 1-17.

Ward, T.B. (2004). Cognition, creativity and entrepreneurship. Journal of Business Venturing, 19(2), 173-188.

Zhou, J. (2008). New look at creativity in the entrepreneurial process. Strategic Entrepreneurship Journal, 2(1), 1-5. 